\title{
Analisis Implementasi Kebijakan Pengaturan Pengoperasian Kendaraan Bentor Sebagai Moda Transportasi Di Gorontalo
}

\author{
${ }^{1}$ Andi Yusuf Katili, ${ }^{2}$ Nolfi S. Tueno \\ ${ }^{12}$ STIA Bina Taruna Gorontalo \\ Gorontalo, Indonesia, 96115 \\ E-mail: yusuf2801@gmail.com ; nolfitueno@gmail.com \\ Received: 03 Maret 2020; Revised: 14 April 2020; Accepted: 28 April 2020
}

\begin{abstract}
Bentor is a modification between a rickshaw and a motorcycle which has become a characteristic of public transportation vehicles or modes of transportation for the people of Gorontalo. Bentor can operate from one place to another, it can even take passengers to household stairs, this cannot be done by other public transportation. This advantage makes most Gorontalo people choose it as the main transportation because it operates 24 hours. The purpose of this study is to conduct an analysis of the implementation of policies on the operation of bentor vehicles as a mode of transportation based on Gorontalo Provincial Regulation No. 6 of 2006. The research method used in this research is descriptive research with a qualitative approach. Data collection techniques are carried out through observation, interviews, and documentation. The results showed that (1) Compliance of Bentor riders with traffic regulations is still low, so it is necessary to take action by the relevant authorities; (2) Coordination between officers of the Transportation Service and the Police in carrying out their duties has not been well established, so that violations continue to occur; (3) The supervision of related offices of apparatus in the field in implementing regional regulations is still low, due to the lack of officers who will be assigned as field supervisors.
\end{abstract}

Keywords: Implementation; Policy; Operational; Bentor

\begin{abstract}
Abstrak
Bentor merupakan modifikasi antara becak dan sepeda motor yang telah menjadi ciri khas kendaraan angkutan umum atau moda transportasi masyarakat Gorontalo. Bentor dapat beroperasi dari suatu tempat ke tempat lain, bahkan dapat mengantar penumpangnya hingga ke tangga rumah, hal ini tidak dapat dilakukan oleh kendaraan umum lainnya. Kelebihan ini yang membuat sebagian besar masyarakat Gorontalo memilihnya menjadi transportasi utama karena beroperasi selama 24 jam. Adapun tujuan penelitian ini adalah untuk melakukan analisis mengenai Implementasi Kebijakan Pengaturan Pengoperasian Kendaraan Bentor Sebagai Moda Transportasi Berdasarkan Peraturan Daerah Provinsi Gorontalo Nomor 6 Tahun 2006. Metode penelitian yang digunakan dalam penelitian ini adalah penelitian deskriptif dengan pendekatan kualitatif. Teknik pengumpulan data dilakukan melalui observasi, wawancara, dan dokumentasi. Hasil penelitian menunjukkan bahwa (1) Kepatuhan pengendara Bentor terhadap peraturan berlalu lintas masih rendah sehingga perlu dilakukan penindakan oleh aparat terkait; (2) Koordinasi antara petugas Dinas Perhubungan dengan Kepolisian dalam melaksakan tugas belum terjalin dengan baik, sehingga pelanggaran pun terus terjadi; (3) Pengawasan dinas terkait terhadap aparat di lapangan dalam menjalankan peraturan daerah masih rendah, karena minimnya petugas yang akan ditugaskan sebagai pengawas lapangan.
\end{abstract}

Kata Kunci: Implementasi; Kebijakan; Operasional; Bentor

Link DOI : http://dx.doi.org/10.31314/pjia.9.1.46-54.2020 
Publik (Jurnal Ilmu Administrasi) Vol 9 (1), Juni 2020

\section{PENDAHULUAN}

Bentor merupakan moda transportasi yang telah menjadi ikon masyarakat Gorontalo yang dibuat dari suatu modifikasi antara becak dan sepeda motor. Bentor memiliki suatu kelebihan dibandingkan dengan moda transportasi lain, karena Bentor dapat beroperasi dari suatu tempat ke tempat lain, bahkan dapat mengantar penumpangnya hingga ke tangga rumah atau door to door, hal ini dijelaskan juga dalam penelitian (Nurwahyudi, 2018). Kelebihan ini yang membuat sebagian besar masyarakat Gorontalo memilihnya menjadi transportasi utama karena beroperasi selama 24 jam. Moda transportasi Bentor pada awalnya belum bermasalah tetapi seiring berjalannya waktu, jumlah Bentor di Gorontalo semakin tidak terkendali, sehingga menyulitkan petugas dalam mengawasi hilir mudik moda transportasi ini.

Dari data diperoleh jumlah Bentor baik terdaftar maupun tidak yang beroperasi di Gorontalo lebih kurang 18.884 unit dan terus bertambah, jumlah yang cukup besar ini telah menimbulkan permasalahan dalam berlalu lintas. Penelitian oleh (Mudana \& Heriwibowo, 2018), bahwa Bentor di Kota Gorontalo berjumlah 11.000 unit. Besarnya jumlah Bentor beroperasi di Gorontalo, sudah tentu menimbulkan permasalahan di bidang transportasi, namun yang memunculkan pertanyaan adalah mengapa, baik oleh Pemerintah Provinsi maupun Pemerintah Kota Gorontalo menerbitkan suatu kebijakan melalui peraturan daerah masing-masing tidak dilakukan pengawasan terhadap implementasi peraturan daerah. Tetapi memang peraturan daerah tersebut bertentangan dengan undang-undang lalu lintas yang hingga saat ini belum mendapatkan izin operasional dari Kementerian
Perhubungan. Hal ini dijelaskan juga oleh Lasswell dan Kaplan dalam (Islamy, 2014) bahwa "kebijakan merupakan suatu program pencapaian tujuan, nilai-nilai dan tindakan-tindakan yang terarah".

Pada dasarnya suatu peraturan akan dibahas, disetujui dan diterbitkan berupa peraturan disebabkan adanya suatu masalah, yang memuat berbagai tindakan dan sanksi agar dipatuhi oleh sasaran atau target peraturan tersebut. Dan suatu kebijakan merupakan "serangkaian tindakan yang diusulkan oleh seseorang, kelompok, atau pemerintah dalam suatu lingkungan tertentu yang memberikan hambatan-hambatan dan peluang-peluang terhadap kebijakan yang diusulkan untuk menggunakan dan mengatasi dalam rangka mencapai suatu tujuan atau merealisasikan suatu sasaran atau suatu maksud tertentu", hal ini dijelaskan oleh Friedrich dalam (Islamy, 2014). Dan suatu kebijakan akan muncul atau diberlakukan di suatu daerah melalui peraturan daerah, misalnya, disebabkan suatu hal yang mengharuskan untuk segera diterapkan dalam rangka mengatasi suatu permasalahan. Contohnya adalah perda yang diterbitkan baik oleh Pemerintah Provinsi Gorontalo maupun oleh Pemerintah Kota Gorontalo. Dimana tujuan adalah mengatasi berbagai kemacetan akibat moda transportasi Bentor semakin hari kian banyak, yang tentu telah dan akan membuat lalu lintas kenderaan sulit diatasi oleh petugas di lapangan.

Fenomena moda transportasi Bentor di Gorontalo telah memunculkan masalah baru bagi pemerintah daerah yang dengan "terpaksa" menerbitkan peraturan daerah. Hal ini sejalan dengan (Tahir, 2016), bahwa "Implementasi kebijakan publik sebagai salah satu aktivitas dalam proses kebijakan publik, sering bertentangan dengan apa yang diharapkan, bahkan menjadikan produk kebijakan itu sebagai batu sandungan bagi pembuat kebijakan itu Copyright (0) 2020, Publik (Jurnal Ilmu Administrasi), ISSN: 2301-573X (Print), ISSN: 2581-2084 (Online) 
sendiri”. Ada dua perspektif yang disampaikan Tachjan yang dikutip oleh (Tahir, 2016) bahwa "suatu kebijakan publik dapat dipahami dari dua prespektif, yaitu: Pertama, prespektif politik, bahwa kebijakan publik di dalam perumusan, implementasi maupun evaluasinya pada hakikatnya merupakan pertarungan berbagai kepentingan publik di dalam mengalokasikan dan mengelola sumber daya (resources) sesuai dengan visi, harapan dan prioritas yang ingin diwujudkan. Kedua, prespektif administratif, bahwa kebijakan publik merupakan ikhwal berkaitan dengan sistem, prosedur, dan mekaninsme, serta kemampuan para pejabat publik (official officers) di dalam menerjemahkan dan menerapkan kebijakan publik, sehingga visi dan harapan yang ingin dicapai dapat diwujudkan di dalam realitas".

Peraturan mengenai keberadaan Bentor sebagai moda transportasi di daerah Gorontalo telah dimulai sejak diterbitkan regulasi melalui Peraturan Daerah Provinsi Gorontalo Nomor 6 Tahun 2006 Tentang Pengaturan Penyelenggaraan Angkutan Kendaraan Bentor, walaupun hingga saat ini belum ada persetujuan dari Kementerian Perhubungan Republik Indonesia tentang Bentor sebagai moda transportasi umum yang memenuhi persyaratan yang aman bagi penumpangnya, tetapi hingga saat ini peraturan daerah tersebut masih menjadi dasar hukum bagi beroperasi kendaraan Bentor sebagai moda transportasi. Adapun yang menjadi permasalahan pelaksanaan kebijakan pemerintah tentang pengaturan pengoperasian Bentor disebabkan pengemudi Bentor sering melanggar ketentuan muatan idealnya 2 orang di depan dan 1 orang duduk di belakang pengemudi Bentor. Tetapi kenyataan muatan Bentor seringkali melampaui batas (over passenger) yakni mencapai 5-7 orang, sehingga sering menyebabkan terjadinya kecelakaan karena pengemudi Bentor tidak dapat mengendalikan kendaraannya. Hal senada dijelaskan juga oleh (Nurwahyudi, 2018), bahwa Bentor mudah mengalami kecelakaan. Oleh sebab itu perlu tindakan tegas dari aparat Dinas Perhubungan dan Kepolisian dengan sering berkoordinasi melakukan pengawasan lapangan yaitu menjaga ketertiban pada jam-jam sibuk agar kesemerawutan lalu lintas dapat diatasi.

Implementasi kebijakan pemerintah tentang pengaturan pengoperasian Bentor berdasarkan peraturan daerah tersebut terkendala disebabkan kurang optimal komunikasi pemerintah daerah tentang peraturan daerah dengan pengemudi Bentor, minimnya sumber daya petugas pelaksana, komitmen pelaksana kebijakan dalam penerapan peraturan mengenai pengoperasian Bentor belum dapat diwujudkan dengan baik, antara lain pemilik Bentor yang belum mendaftarkan kendaraannya, sehingga banyak Bentor yang beroperasi di Gorontalo tidak memiliki izin operasi. Selain itu struktur birokrasi yaitu keterlibatan lembagalembaga atau instansi terkait dalam pelaksanaan kebijakan tentang pengaturan pengoperasian Bentor belum berjalan sesuai harapan, misalnya sebagian besar Bentor belum menaati peraturan lalu lintas seperti memuat penumpang melampaui batas maksimal, serta menaikan dan menurunkan penumpang bukan di tempat yang ditentukan sehingga menyebabkan sering terjadi kecelakaan dan kemacetan arus lalu lintas dikarenakan baik aparat Dinas Perhubungan maupun aparat Kepolisian belum tegas dalam melakukan tindakan.

Untuk diketahui bahwa Peraturan Daerah (Perda) merupakan produk 
legislatif dan pemerintah dalam mengatur suatu kehidupan yang terkait dengan warga masyarakat. Implementasi peraturan daerah dalam konsep teori dikategorikan sebagai implementasi kebijakan program pembangunan. Program pembangunan bukan berarti hanya membangun fisik, tetapi lebih luas dan kompleks sifatnya. Hal senada dijelaskan oleh Bryant dan White dalam (Effendi, 2014); bahwa konsep pembangunan yang ditujukan untuk membangun masyarakat pada umumnya "sering memunculkan interpretasi-interpretasi yang beragam, dengan menggunakan istilah pembangunan sebagai usaha untuk perubahan, modernisasi, pembaharuan, pembahasan dan pembinaan. Dalam pengertian di atas, membiasakan hidup teratur di kalangan masyarakat dengan menerapkan peraturan daerah, merupakan bagian dari kegiatan pembangunan yaitu membangun martabat manusia. Karena pada dasarnya pembangunan itu sendiri sering dirumuskan sebagai proses perubahan yang terencana dari suatu situasi nasional ke situasi nasional yang lain yang dinilai lebih tinggi dengan kata lain pembangunan menyangkut proses perbaikan. Hal ini juga dikatakan oleh (Wirutomo, 2013), (Ranjabar, 2015), dan (Yulhendri, 2019).

Pembangunan adalah kegiatan yang tidak berjalan di tempat, tetapi merupakan gerakan yang terus berkelanjutan dan dinamis. Hal ini dikemukakan juga oleh (Tjokroamidjojo, 2001), "pengertian pembangunan harus dilihat secara dinamis dan bukan sebagai konsep statis". Karena menurut Todaro dalam Bryant dan White dalam (Effendi, 2014) "pembangunan juga merupakan proses multidimensi yang mencakup perubahan-perubahan penting dalam struktur sosial, sikap-sikap rakyat dan lembaga-lembaga nasional dan juga akselerasi pertumbuhan ekonomi, pengurangan kesenjangan "inequality" dan pemberantasan kemiskinan absolut". Implementasi program juga sebagaimana dikemukakan di atas, melibatkan sejumlah interaksi di antara badan-badan yang terlibat, maka koordinasi merupakan hal yang sangat penting. Koordinasi merupakan usaha untuk menjamin kelancaran mekanisme kerja dari berbagai komponen, baik di dalam maupun di luar organisasi. Kelancaran mekanisme prosedur kerja harus dapat menjamin dalam rangka pencapaian tujuan orgnisasi dengan menghindari seminimal mungkin perselisihan yang timbul antara sesama komponen organisasi dan mengusahakan semaksimal mungkin kerjasama di antara komponen-komponen tadi. Oleh karena itu, koordinasi merupakan salah satu faktor dominan yang perlu diperhatikan bagi kelangsungan hidup suatu organisasi. Dikatakan sebagai salah satu faktor dominan, karena bagi kelangsungan hidup suatu organisasi pada tingkat tertentu, sangat ditentukan oleh kualitas usahausaha yang dijalankan. Berdasarkan uraian teori yang dikemukakan di atas, persoalan implementasi kebijakan pemerintah daerah sangat terkait dengan persoalan birokasi. Dalam arti bahwa penetapan kebijaksanaan pengaturan pengoperasian kendaraan bentor tersebut bukan hanya kepentingan birokrasi tetapi adalah kepentingan masyarakat itu sendiri, sehingga mereka harus dilibatkan dalam penetapan kebijaksanaan tersebut.

Tujuan penelitian ini lebih menekankan kepada peraturan daerah (Peraturan Daerah Provinsi Gorontalo, 2006) tentang pengaturan penyelenggaraan angkutan kendaraan Bentor di wilayah Gorontalo, yang dilihat dari aspek kepatuhan, koordinasi, dan pengawasan. Sementara penelitian yang dilakukan oleh (Ketut \& Heriwibowo, 2016) hanya melihat dari sisi aspek regulasi dan keselamatan. Demikian juga penelitian Copyright (c) 2020, Publik (Jurnal Ilmu Administrasi), ISSN: 2301-573X (Print), ISSN: 2581-2084 (Online) 
yang dilakukan oleh (Nurwahyudi, 2018) hanya melihat dari sisi karakteristik dan prasarana. Selanjutnya penelitian yang dilakukan oleh (Lintang, Supardjo, \& Karongkong, 2016) hanya melihat dari pengguna jasa dan kualitas pelayanan.

Dengan demikian penelitian yang dilakukan ini sangat berbeda dalam fokus penelitian-penelitian sebelumnya yang telah dipublikasi oleh peneliti-peneliti terdahulu pada jurnal-jurnal yang ada. Selain itu, penelitian ini juga berbeda dalam lingkup lokasi penelitian, karena peneliti melakukan studi kepustakaan berdasarkan fenomena di lapangan.

\section{METODE PENELITIAN}

Penelitian ini menggunakan jenis deskriptif dengan pendekatan kualitatif, dimana pengumpulan data dilakukan melalui observasi, wawancara dan dokumentasi seperti yang dijelaskan oleh (Sugiyono, 2016); (Mukhtar, 2013); dan (Herdiansyah, 2010). Untuk melihat fenomena yang terjadi, maka penelitian ini juga menggunakan metode triangulasi $(H$. Mudjia Rahardjo, 2010), dan (Bachri, 2010). Melalui metode ini diharapkan hasil penelitian ini dapat dijadikan rujukan untuk menegakkan peraturan pengoperasian Bentor sebagai moda transportasi di Gorontalo yakni: 1) Penegakan kepatuhan pengendara Bentor dalam berlalu lintas di jalan raya; 2) Koordinasi antara petugas Dinas Perhubungan dan kepolisian harus ditingkatkan agar tidak terjadi pelanggaran dalam berlalu lintas; 3) Pengawasan dinas terkait terhadap petugas yang melaksanakan kebijakan sesuai peraturan daerah sehingga pelanggaran terhadap berlalu lintas dapat dikurangi dan diberikan sanksi?

Adapun yang menjadi informan dalam penelitian ini adalah dinas terkait dalam hal ini Dinas Perhubungan dan Kepolisian.

\section{HASIL DAN PEMBAHASAN}

Pelaksanaan pengaturan adalah proses, cara atau perbuatan mengatur. Artinya adalah kegiatan dalam proses melakukan sesuatu melalui mekanisme atau prosedur yang telah ditetapkan. Pengaturan penyelenggaran kendaraan Bentor merupakan salah satu bentuk proses pengawasan dan pengendalian terhadap sarana angkutan antara tingkat perkembangan dan pertumbuhan jumlah kendaraan angkutan dan perkembangan arus lalu lintas yang dapat meminimalisasi kesemrawutan arus lalu lintas. Untuk itu diperlukan suatu tindakan penegakan hukum yang tegas sehingga menciptakan koordinasi angkutan yang layak bagi pengguna dan terciptanya suatu tatanan berlalu lintas yang aman, tertib dan lancar.

Pengoperasian adalah proses, cara atau perbuatan mengoperasikan. Artinya adalah suatu kegiatan yang dilakukan oleh seseorang atau lembaga yang di dalamnya menyangkut pengoperasian sarana angkutan transportasi bentor. Pelaksanaan kebijakan pemerintah tentang pengaturan pengoperasaian Bentor tidaklah maksimal. Oleh Karena itu masih perlu kajian yang mendalam tentang pelaksanaan pengaturan pengoperasian Bentor tersebut. Mengingat masyarakat Gorontalo sangat membutuhkan sarana angkutan transportasi Bentor. Selain itu pemerintah daerah memberikan batasan tentang produksi Bentor agar tidak semakin banyak beroperasi di wilayah Gorontalo. Terkait dengan upaya pihak dinas perhubungan dalam melaksanakan dan mengawasi implementasi kebijakan pemerintah terhadap pengaturan pengoperasian Bentor di Gorontalo adalah bertujuan untuk demi menjaga keselamatan penumpang, yang 
ternyata dalam praktek di lapangan masih mengalami kendala seperti kurangnya sumberdaya manusia.

Adapun hasil penelitian lapangan berdasarkan analisis implementasi peraturan daerah dimaksud dan studi kepustakaan, maka dapat diuraikan sebagai berikut:

\section{Penerbitan Peraturan Daerah}

Peraturan daerah merupakan produk bersama antara pemerintah daerah dan lembaga legislatif, hal ini merupakan bentuk kepedulian kedua institusi tersebut terhadap kelangsungan hidup masyarakat, terutama para penumpang dan pengemudi Bentor sebagai moda transportasi di Gorontalo, yang terus bertambah dan semakin membuat arus lalu lintas kian tak terkendali. Berdasarkan kondisi tersebut maka Pemerintah Daerah Provinsi Gorontalo menerbitkan Nomor 6 (Peraturan Daerah Provinsi Gorontalo, 2006) tentang Pengaturan Penyelenggaraan Angkutan Kendaraan Bentor yang tujuannya adalah "untuk menjaga keselamatan, kenyamanan, kelestarian lingkungan dan pelayanan angkutan umum serta menjaga keseimbangan perkembangan kendaraan Bentor dengan perkembangan jalan yang dapat berakibat pada terjadinya ketidaktertiban lalu lintas". Dan salah satu hal yang dijelaskan dalam perda tersebut yang dapat dikategorikan dapat mengurai kepadatan lalu lintas dengan adanya keberadaan moda transportasi Bentor di Gorontalo adalah mengenai keharusan atau kewajiban izin produksi dan warna Bentor di suatu wilayah.

Moda transportasi Bentor kehadirannya tidak dapat ditolak karena telah menjadi kebutuhan masyarakat dalam beraktivitas tanpa batas waktu. Selain itu kehadiran Bentor telah dapat meningkatkan geliat perekonomian, juga mengurangi pengangguran. Copyright (C) 2020, Publik (Jurnal Ilmu Administrasi), ISSN: 2301-573X (Print), ISSN: 2581-2084 (Online)
Oleh karena Bentor konstruksinya labil, maka mudah mengalami kecelakaan, sehingga salah satu bantuan yang dapat diberikan oleh pemerintah adalah mewajibkan para pengemudi sebagai peserta asuransi jasa raharja, yang sesuai dengan ketentuan pada pedoman jasa raharja (Jasaraharja, n.d.).

Pada kenyataan di lapangan, penerapan aturan tersebut tidak sesuai atau tidak terlihat nyata, hal ini disebabkan pelaksana atau petugas lapangan seperti dinas terkait tidak melakukan kontrol atau pengawasan terhadap produksi Bentor. Selain itu, dinas terkait belum sepenuhnya melakukan sosialisasi kepada pemilik kendaraan Bentor mengenai warna Bentor sesuai wilayah operasional moda transportasi tersebut. Akibatnya terjadi penumpukan Bentor tanpa dapat dikendalikan oleh aparat terkait, dimana pengemudi Bentor beroperasi dan berhenti "sesuka hati" atau bukan pada tempat seharusnya berhenti, sehingga seringkali menimbulkan kemacetan terutama pada jam-jam sibuk. Selain itu, oleh karena Bentor merupakan moda transportasi, maka di dalam Peraturan Menteri Perhubungan Nomor 108 Tahun 2017 "dapat" diketagorikan sebagai kendaraan pengangkut orang tidak dalam trayek, karena Bentor dapat berjalan kemana tujuan penumpang. (Peraturan Menteri Perhubungan, 2017).

\section{Undang-Undang Lalu Lintas}

Sesungguhnya sebuah peraturan, apalagi berbentuk undang-undang merupakan peraturan tertinggi di Negara Kesatuan Republik Indonesia (NKRI) dan menjadi dasar hukum yang harus dipatuhi oleh semua unsur yang ada di dalam negara. Demikian pula dengan undangundang tentang lalu lintas yaitu UndangUndang Nomor 22 Tahun 2009 Tentang Lalu Lintas Angkutan Jalan (Indonesia, 2009), yang mengatur tentang berbagai 
operasional kendaraan di jalan raya. Namun pada kenyataannya ada peraturan daerah mengenai operasional kendaraan di jalan raya bertentangan dengan undangundang tersebut. Adapun peraturan daerah yang dimaksud adalah Peraturan Daerah Nomor 6 Tahun 2006 Pengaturan Penyelenggaraan Angkutan Kendaraan Bentor (Peraturan Daerah Provinsi Gorontalo, 2006), yang mengatur mengenai moda transportasi Bentor yang merupakan ikon atau telah menjadi khas daerah Gorontalo dalam berlalu lintas.

Hal-hal yang sering dilanggar oleh pengemudi Bentor di Gorontalo adalah memuat penumpang melebihi kapasitas, yang idealnya dua penumpang di depan dan seorang di belakang pengemudi. Tetapi dalam kenyataan pengemudi menerima penumpang lebih dari tiga orang, dimana yang sering terjadi adalah lima di depan dan dua di belakang pengemudi. Tentu saja kelebihan muatan ini dapat menyebabkan kecelakaan berat karena pengemudi tidak dapat melihat situasi jalan di depannya. Selain itu karena setir merupakan tempat duduk penumpang, maka untuk berbelok pun pengemudi harus ekstra hati-hati. Muatan yang berat menyebabkan rem untuk melambatkan atau menghentikan kendaraan Bentor tidak maksimal dapat dilakukan.

\section{Penegakan Aturan / Sanksi}

Produksi kendaraan Bentor hingga saat ini masih terus berlangsung, hampir tanpa kendali, padahal dalam salah satu pasal pada (Peraturan Daerah Provinsi Gorontalo, 2006) tersebut, dijelaskan bahwa "Badan usaha yang memroduksi kendaraan Bentor harus mendapat izin dari Pemerintah Kabupaten/Kota melalui instansi yang membidangi industri”. Pada pasal yang lain dijelaskan bahwa "permohonan pengoperasian kendaraan Bentor wajib memenuhi persyaratan yaitu (a) Surat izin operasi yang dikeluarkan dari Pemerintah Kabupaten/Kota; (b) Tanda nomor kendaraan bermotor (TNKB) dengan dasar hitam tulisan putih; (c) Mengansuransikan penumpang dan pengemudi melalui PT. Jasa Raharja (Persero). Selain itu pengemudi kendaraan Bentor wajib memiliki Surat Izin Mengemudi (SIM) dari Kepolisian; dan Permohoan pengujian berkala kendaraan Bentor lebih lanjut diatur oleh Pemerintah Kabupaten/Kota berdasarkan domisili pemilik". Selain itu ada pasal lain mengenai sanksi adalah bahwa pelanggaran terhadap ketentuan tersebut diancam pidana kurungan paling lama 6 (enam) bulan atau denda paling banyak Rp.600.000 (enam ratus ribu rupiah). Pada kenyataan pasal-pasal tersebut tidak pernah dilaksanakan atau lebih sering dilanggar atau tidak dipatuhi baik oleh aparat maupun produsen kendaraan Bentor, dimana bukan berkurang jumlahnya tetapi semakin banyak dan tidak terkendali.

Sementara peneliti menemukan sebagian pengemudi kendaraan Bentor tidak memiliki SIM dan "main kucingkucingan" dengan petugas ketika ada pelaksanaan penertiban kendaraan yang dilakukan oleh Kepolisian dan Dinas Perhubungan. Selain itu pengemudi dan penumpang tidak memiliki asuransi kecelakaan. Bahkan tidak pernah melakukan pengujian berkala kendaraan Bentor, tentu telah melanggar Peraturan Menteri Perhubungan Nomor 156 Tahun 2016 Tentang Kompetnsi Pengujian Kendaraan Bermotor (Peraturan Menteri Perhubngan RI, n.d.). Ada hal yang cukup menarik dalam (Peraturan Daerah Provinsi Gorontalo, 2006), yaitu sanksi pidana bagi pelanggar, tetapi hal ini tidak pernah dijalankan, ditegakkan, baik kurungan badan maupun denda administrasi, sehingga bagi pengemudi Bentor menduga 
bahwa peraturan hanyalah suatu bentuk tulisan yang tidak memiliki atau tidak mengikat bagi mereka. Oleh karena tidak pernah diterapkan sanksi-sanksi yang tertera dalam peraturan daerah tersebut, maka tindak pelanggaran pun terus terjadi di semua tingkat wilayah operasional moda transportasi Bentor di Gorontalo.

\section{PENUTUP}

\section{Kesimpulan}

Berdasarkan hasil penelitian yang telah dilakukan, maka dapat disimpulkan bahwa moda transportasi Bentor bagi masyarakat Gorontalo sudah merupakan kebutuhan yang tidak dapat ditolak keberadaannya, walaupun pada kenyataannya (Peraturan Daerah Provinsi Gorontalo, 2006) Tentang Pengaturan Penyelenggaraan Angkutan Kendaraan Bentor yang telah diterbitkan bertentangan dengan, baik terhadap Undang-Undang Nomor 22 Tahun 2009 Tentang Lalu Lintas Angkutan Jalan (Indonesia, 2009) maupun Peraturan Menteri Perhubungan Nomor 156 Tahun 2016 Tentang Pengujian Kendaraan Bermotor, karena menurut para pengemudi bahwa Bentor mereka tidak pernah melakukan pengujian kendaraan bermotor.

\section{Saran}

Hal yang dapat disarankan dari kesimpulan berdasarkan (Peraturan Daerah Provinsi Gorontalo, 2006), maka berbagai pasal yang telah dicantumkan dalam peraturan daerah tersebut sebaiknya dilaksanakan secara konsisten, dimana tujuan utama adalah melindungi keselamatan masyarakat yaitu penumpang dan pengemudi Bentor. Walaupun sejatinya prototipe Bentor bukan atau tidak layak sebagai moda transportasi angkutan orang karena rawan kecelakaan.

\section{DAFTAR PUSTAKA}

Bachri, B. S. (2010). Meyakinkan validitas data melalui triangulasi pada penelitian kualitatif. Jurnal Teknologi Pendidikan, 10(1), 46-62.

Effendi, S. (2014). Implementasi dan Evaluasi Kebijakan Publik. Yogyakarta: MAP UGM.

H. Mudjia Rahardjo. (2010). Triangulasi dalam Penelitian Kualitatif. https://doi.org/10.1360/zd-2013-43-61064

Herdiansyah, H. (2010). Metodologi penelitian kualitatif untuk ilmu-ilmu sosial. Jakarta: Salemba Humanika.

Indonesia, P. R. (2009). Undang-Undang Lalu Lintas Nomor 22 Tahun 2009.

Islamy, I. (2014). Definisi dan Makna Kebijakan Publik. ADPU4410/Modul 1, 1-41. https://doi.org/http://repository.ut.ac.i d/3993/1/ADPU4410-M1.pdf

Jasaraharja, P. A. (n.d.). Pedoman Asuransi Jasaraharja.

Ketut, M. I., \& Heriwibowo, D. (2016). Pengoperasian Becak Motor (Bentor) di Wilayah Kota Gorontalo, 28(2), 130-145.

Lintang, T. V. A., Supardjo, S., \& Karongkong, H. H. (2016). Evaluasi Pelayanan Transportasi Bentor di Kota Kotamobagu Berdasarkan Persepsi Pengguna. SPASIAL, 3(3), 146-155.

Mudana, I. K., \& Heriwibowo, D. (2018). Pengoprasian Becak Motor (Bentor) di Wilayah Kota Gorontalo. Warta Penelitian Perhubungan. https://doi.org/10.25104/warlit.v28i2. 691

Mukhtar. (2013). Metode Praktis Penelitian Deskriptif Kualitatif. Jakarta: Referensi (GP Press Group.

Nurwahyudi, $\quad$ M. (2018). Studi Copyright @ 2020, Publik (Jurnal Ilmu Administrasi), ISSN: 2301-573X (Print), ISSN: 2581-2084 (Online) 
Perencanaan Prasarana Jaringan

Transportasi Moda Becak-Motor

Bemor Di Kota Makassar. Jurnal

Teknik Sipil: Rancang Bangun. https://doi.org/10.33506/rb.v4i2.172

Peraturan Daerah Provinsi Gorontalo. (2006). Peraturan Daerah Provinsi Gorontalo Nomor 6 Tahun 2006 Tentang Pengaturan Penyelenggaraan Angkutan Kendaraan Bentor.

Peraturan Menteri Perhubngan RI. (n.d.). Peraturan Menteri Perhubungan No_PM_156_Tahun_2016.pdf.

Peraturan Menteri Perhubungan. (2017). Peraturan Menteri Perhubungan_NO._108_Tahun 2017.

Ranjabar, J. (2015). Perubahan Sosial: Teori-Teori dan Proses Perubahan Sosial serta Teori Pembangunan. Bandung: Alfabeta.

Sugiyono. (2016). Memahami Penelitian Kualitatif. Bandung: Alfabeta.

Tahir, A. (2016). Analysis of public service quality at Department of Population and Civil Registration in Gorontalo City. International Journal of Applied Business and Economic Research.

Tjokroamidjojo, B. (2001). Good Governance, Paradigma Baru Manajemen Pembangunan (2nd ed.). Jakarta: Lembaga Administrasi Negara.

Wirutomo, P. (2013). Mencari Makna Pembangunan Sosial: Studi Kasus Sektor Informal di Kota Solo. MASYARAKAT: Jurnal Sosiologi. https://doi.org/10.7454/mjs.v18i1.373 5

Yulhendri, Y. (2019). Pembangunan: Modal Manusia dan Modal Sosial. 